\title{
Ecoinnovations in European countries
}

\author{
Pawel Bartoszczuk
}

\author{
Enterprise Institue, \\ Warsaw School of Economics \\ Warsaw, Poland \\ pbarto1@sgh.waw.pl
}

\begin{abstract}
The goal of this paper is to present eco-innovation implementation in some European countries. Expected environmental law is very important for enforcing firm to minimise emission to air and water, diminish amount of hazardous substances and increase recycling. Cost reduction is another incentive for lower energy and material consumption, pointing to the significance of energy and materials prices, together with tax as ecoinnovation drivers. Customer wants are important basis for ecoinnovations, particularly with regard to green products and process innovations that improve material efficiency, reduce consumption of energy and waste creation. In the paper we present ecoinnovation examples from Poland and Denmark.
\end{abstract}

Keywords-ecoinnovation; green economy; European countries;

\section{INTRODUCTION}

Globalisation, technological progress, ever shorter life cycles, increasing pollution, and fast changing of customers demand have involved that company's competitiveness is more related to the ability to ecoinnovate. Even though much eco-innovation research has been published, no agreed definition of eco-innovation (environmental innovation) has been emerged to date [1].

Problems concerning the processes of generation and absorption of innovations favouring the environment (ecoinnovations) are a subject of interest to scientific communities, economic entities and public authorities for some period. Ecoinnovation concept appeared very late in economics -in the 90 's of XX century as response to continuously deteriorating environment and increasing interest in innovations, which contribute to the competitive growth of firms and economic development. First definition was given by [2], who described them as beneficial both to producers and consumers, and simultaneously decreasing negative impact on environment. The reason underlying is that this category is difficult to define, requiring both theoretical knowledge and practical research.

Availability of data on ecoinnovation was very occasional until the Eurostat Community Innovation Survey (CIS) in 2008 and most recent available survey of 2010. This paper uses the Eurobarometer data [3], which is designed on the ecoinnovation and thus has the benefit of including both specific questions on eco-innovation investment and material costs. The targeted sample is the full EU27, in contrast to a sample of EU countries targeted by the CIS. Furthermore, the Eurobarometer is the most recent conducted survey on the papers specific topic, with a dataset that has the potential of providing new insights on eco-innovation determinants related to resource efficiency.

The paper consists of 5 chapters, including introduction. In second chapter we present literature review concerning ecoinnovation, in the third results of ecoinnovation development in Europe, the fourth present case study: Poland and Denmark, forth present econometric example and fifth conclusion.

\section{LITERATURE REVIEW}

In this study, we used [4] definition of ecoinnovation. "Ecoinnovation is the introduction of any new or significantly improved product (good or service), process, organizational change or marketing solution that reduces the natural resources use (including materials, energy, water and land) and decreases the release of harmful substances across the whole life-cycle". An environmental innovation creates environmental benefits compared to the alternatives. The environmental benefits can be the primary objective of the innovation or the result of other objectives. These benefits can happen during the production of a good or service, or during consumption of them.

One of the main expected results of eco-innovation is the increase of environmental effectiveness, meaning reduction of energy consumption, and in this way increasing business competition [5]. Still, the preparation and implementation of the eco-innovation is undertaken in order to build a sustainable competitive advantage. In the most conducted econometric studies to date, environmental innovations were widely analyzed while only a few papers distinguished between end - of - pipe - innovations (EOP) and 
cleaner production ones. In the literature, there is an agreement that eco-innovations are regulation driven though significant number of studies emphasizes also cost - savings. It is especially true for cleaner production (CP) technologies, where the reduction cost is important driver of eco-innovation [6] [7]. However, due to deficiency of more differentiated data, the literature on driving forces of eco-innovations to date has ignored to analyze different areas of environmental impacts of eco-innovations such as recycling, low carbon technologies or innovations for water management [8]. Reference [8] also emphasizes the function of customer benefits as an important determinant for eco-innovations. Important findings were given by [9] who suggested that innovation in companies were driven rather by internal country's regulation, not by foreign one. Other researchers demonstrated further incentives to be very crucial. Reference [10] conducted a survey in the Spanish pulp and paper industry. He found that law pressure and company image as the main drivers of cleaner technology implementation. Reference [7] found that generally policy stringency is an important incentive for ecoinnovations rather than single policy instruments. Other researchers, like [11] found similar result for the influence of environmental regulation on green R\&D. Facilities facing very stringent environmental regulation more often lead environmental R\&D. Reference [7] claim that the effects of regulation can be different regarding different environmental technology areas.

Eco-innovation can be developed not only by firms but also by non-profit organizations. They can be traded on different kinds of innovations: technological, organizational, social and institutional [12] There is a common agreement that eco-innovation is great chance for business. By this innovation we are able to introduce: new processes and products and changing business models to increase competitiveness in new and changing markets. Eco-innovation in companies have positive economics effect since it leads to reduced costs, improves capacity to capture new growth opportunities as well as strengthens company image by customers [4]. We argue that eco-innovation in European companies is key to the constant transformation needed toward sustainable development and to meet the EU's vision of a green economy. This transition does not have to be only burden for business, but rather a great opportunity for strategic investment. It asks how business and policy can reduce risk to ensure these opportunities are met.

Other interesting definition of eco-innovation was demonstrated by [13]. An environmental innovation, according to them, is defined as "a new or significantly improved product (good or service), process, organizational method or marketing method that creates environmental benefits compared to alternatives". The environmental benefits can be the main goal of the innovation or can be even not intended. In what follows is a list of environmental benefits for which surveyed firms ought to confirm whether this benefit has occurred or not. Concerning environmental product innovations, ZEW (Centre for European Research) econometric results proved that present regulations are only effective for of air, water, soil and noise emissions reductions but not appropriate for energy and recycling [14]. The firms presume an increasing importance of future regulations for all product ecoinnovations. Environmental regulation and individual environmental policy instruments (specially, soft regulation) are important drivers particularly for eco-product innovations [15], [6] and [16]. Other researchers like [17] imply that firms implement environmental product innovation to obey with existing and anticipated legal requirements. Reference [6] finds a significant positive influence of subsidies on environmental product innovation. Reference [8] demonstrate that a high level of regulatory stringency incentivises companies to implement environmental product innovations which are quite novel to the firm, but this result cannot be corroborated when these innovations are new to the market. Finally, [18] approve importance of planned future regulations for all product innovations.

Since [12] contribution, the unique features of ecoinnovation with respect to standard innovations have been outlined and refined. A key fact is that eco-innovation are characterised as having a "double externality" nature: on the one hand, they reduce negative environmental externalities and, on the other hand, they are themselves subject to externalities, which are driven by knowledge spillovers that could potentially lead to sub-optimal investments. Further, eco-innovation are characterized by the regulatory push-pull effect, as they are strongly regulation driven, and regulation might act both on the supply (push) and on the demand side (pull) [15]; [19]. Finally, eco-innovation adoption depends on social and institutional innovations as well [12].

\section{RESULTS OF ECOINNOVATIONS}

Many European companies implement eco-innovation, nevertheless the majority either still does not introduce that type of innovation or the material savings gained due to innovation are minor. Nevertheless, there is hard, often unrealized potential for ecoinnovation in the EU [4]. Around $25 \%$ innovating companies in the EU-27 have reported introducing eco-innovation to reduce material use between 2006 and 2008, according to the Community Innovation Survey/CIS/ [20]. Up to $45 \%$ of EU companies in the manufacturing, construction, agriculture, water supply and 
food services sector reported implementing eco-innovation in the period 2009-2011. Eurobarometer survey [3] showed that the majority of them achieving incremental type improvements in resource efficiency of 4 . While these are positive events-seeming to indicate a greater push for material efficiency in companies - there is still a large gap between the great potential for eco-innovation and the state of ecoinnovation in the EU countries [3]. Almost 30\% EU companies had introduced a new or significantly improved eco-innovative production process or method in the previous two years, while $24 \%$ had implemented a new or significantly improved eco-innovative organizational method. A similar proportion $(25 \%)$ had introduced a new or significantly improved eco-innovative product or service on the market (Figure 2) [3].

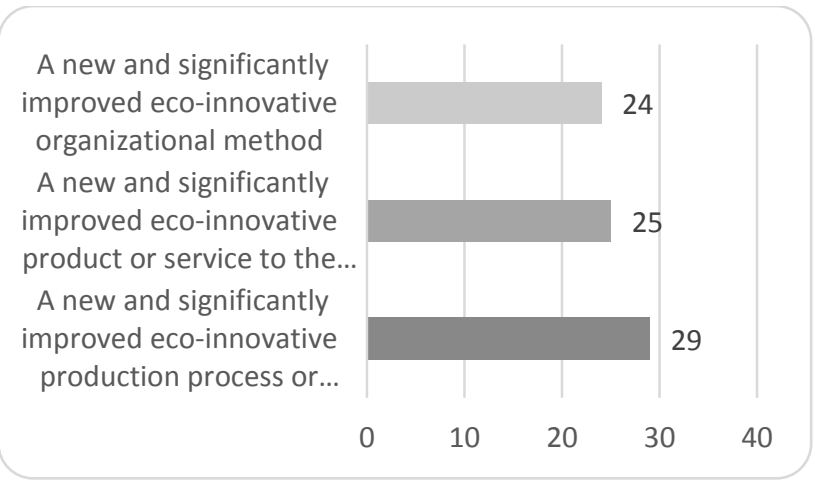

Figure 1 Introduction of various eco-innovations in the past 2 years Source: [3] Attitudes of European entrepreneurs towards eco-innovation Summary Fieldwork: January 2011, Publication: March 2011

More than $40 \%$ companies in the EU informed having introduced at least one eco-innovation in the period 20092011. Unexpectedly, Polish companies were the leaders- they have introduced a new or significantly improved ecoinnovative product or service, production process or organizational method in the two years $(63 \%)$; companies in Hungary were the least expected to implement (27\%), (Figure 2).

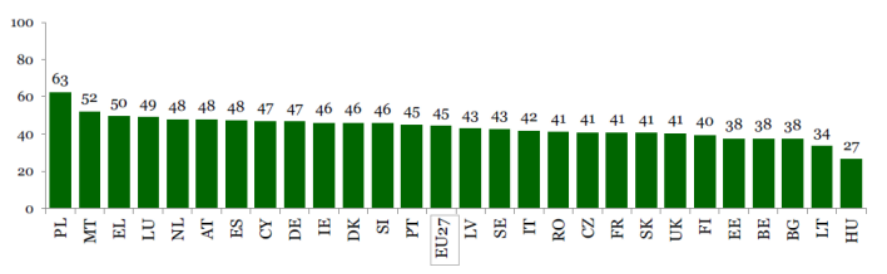

Figure 2 Companies that introduced at least one eco-innovation in past two years in Europe

Source: Attitudes of European entrepreneurs towards eco-innovation Summary Fieldwork: January 2011
Medium-sized companies, companies with an annual turnover $€ 10-50$ million and those that that increased turnover in the previous period were more probably to have introduced the types of eco-innovation enumerated in the Eurobarometer questionnaire [3]. For example, one-third of medium-sized firms introduced a new or significantly improved ecoinnovative organizational method in the past years and $41 \%$ a new or significantly improved production method or process; the analogous figures for small firms were $22 \%$, and $26 \%$, correspondingly.

There is a large gap both in the scale of eco-innovative activities, with large differences between countries, sectors, and sizes of companies as well as a gap in the scope of ecoinnovation changes, with a tendency towards more incremental rather than radical changes introduced to the market. The gap between innovators and eco-innovators is significant across the EU. In Germany around 39\% of innovators are eco-innovating [4], while only $10 \%$ in Bulgaria and Cyprus (see Figure 3). If one looked at the share of ecoinnovators in total companies, only around $15 \%$ of companies across the EU have reported eco-innovative activity focused on material efficiency. In Poland there is little innovation (located on the penultimate place in the CIS ranking). Ecoinnovators are about $22 \%$ of the total innovators in Poland .

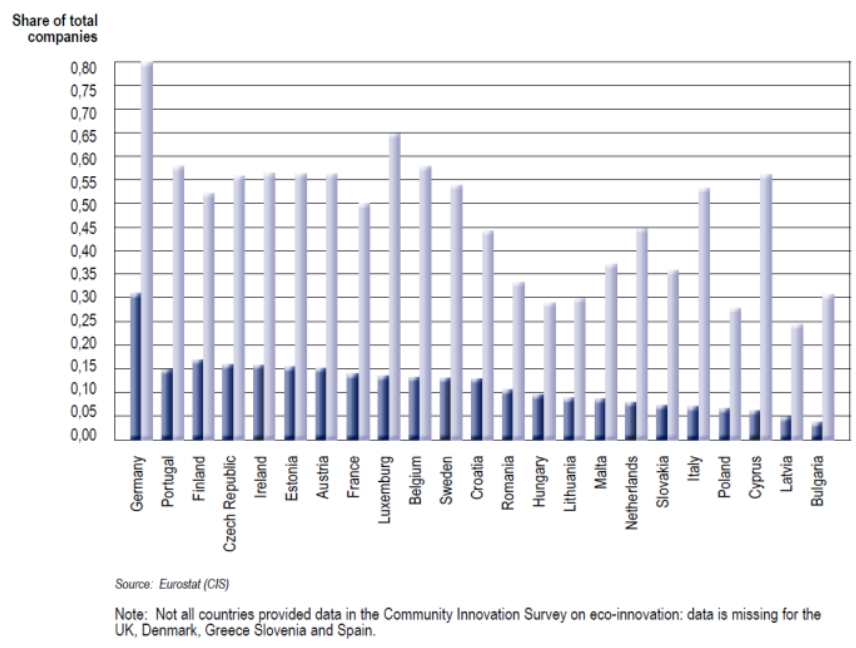

Figure 3 Share of European companies implementing ecoinnovation

We argue that this share is insufficient. Especially, innovative companies already have capacity to capture benefits from improved resource efficiency. Closing the gap in the performance between countries may also add up to greater savings at the macro level. As regards the gap between incremental and radical eco-innovation, still little is known. In the past many firms have become increasingly alert of overarching environmental challenges and have begun preparing their products and services to meet the wave of "green consumption" that has swept across Europe [21]. While there is a general tendency towards 'eco-friendly' products, 
particularly evident in the proliferation of eco-labels over the past 5 years, the trend toward increasing consumption of natural resources in the EU has continued. This indicates that the intensity of changes have not been sufficient to counteract the overall trend [21]. Economic growth has continued to require less additional final energy consumption within the EU-27 economy. However, this improvement has not been sufficient to prevent total final energy consumption. Decoupling was most successful in the industry sector as a result of technical improvements and structural changes, while private households consumed more energy per capita due to larger and more dwellings and more electrical appliances. While energy intensity continues to decline at a faster rate in the new EU-10 Member States, it remains much higher than in the EU-15. There is not, yet, evidence of systemic change, which actually contributes to an absolute decrease of environmental pressures and impacts. This report aims to provide information about the scope of economic benefits for companies to encourage companies to grasp these opportunities and close the eco-innovation gap (Tab.1).

\section{TABLE I}

THE REASONS OF INTRODUCTION OF ENVIRONMENTAL INNOVATIONS (ECO- INNOVATIONS)

\begin{tabular}{|c|c|c|c|}
\hline \multirow{2}{*}{$\begin{array}{l}\text { Environmental } \\
\text { innovations that were } \\
\text { introduced in response to }\end{array}$} & Yes & No & \multirow{2}{*}{$\begin{array}{l}\text { Number of } \\
\text { firms }\end{array}$} \\
\hline & \multicolumn{2}{|c|}{$\begin{array}{l}\text { In \%of all firms } \\
\text { with at least weak } \\
\text { environmental } \\
\text { impacts }\end{array}$} & \\
\hline Existing regulations & 31.5 & 68.5 & 3733 \\
\hline Expected regulations & 27.0 & 73.0 & 3730 \\
\hline $\begin{array}{l}\text { Financial support by } \\
\text { governments }\end{array}$ & 9.9 & 90.1 & 3733 \\
\hline Demand from customers & 27.4 & 72.6 & 3733 \\
\hline $\begin{array}{l}\text { Voluntary codes and } \\
\text { industry agreements }\end{array}$ & 28.0 & 72 & 3727 \\
\hline
\end{tabular}

The European Eco-innovation Action Plan states that European environmental legislation has been one of the most important drivers for eco-innovation. Moreover, the Plan paid attention to some aspects that should be considered in the design, revising or implementation of environmental regulation. One of these is the innovation as an opportunity to improve the environment through flexibility in technological standards. This aspect is directly linked to IPPC Directive, also because the pollution prevention schema could be considered as organisational eco-innovation [21].
Over a third of European firms demonstrated that almost $10 \%$ of investments innovation in the past five year's period were linked to ecoinnovation and a quarter estimated that this share was between $10 \%$ and $29 \%$ [3]. In six countries, more than $20 \%$ of surveyed companies estimated that $30 \%$ of their innovation investments were ecological ones: Sweden $-21 \%$, Greek-22\%, Austrian-23\%, Cyprus and Luxembourg -both $24 \%$ and Polish $-30 \%$. Firms that had significant ecoinnovation investments were more likely to be found in the water and waste sector, and agriculture. Roughly one third companies in the EU had introduced a new or significantly improved ecoinnovative production process or method in the previous two year period, while roughly a quarter had introduced a new or significantly improved eco-innovative organisational method. A similar share $(25 \%)$ had introduced a new or significantly improved eco-innovative product or service on the market.

Among firms demonstrating implementation of at least one type of ecoinnovation in the past period, the largest share (42\%) claimed that such ecoinnovation brought a reduction in material use of 5-19\% per unit of output, while almost a third estimated that the reduction in material consumption had been less than $5 \%$ per unit of output.

The results also show that the attitudes of European entrepreneurs towards current high material prices have the expected impact in eco-process innovations (a positive correlation), which is consistent with previous empirical studies [7] and [6]). Giving importance to cost-related factors is also correlated with the implementation of EOP and cleaner production technologies. On the other hand, the variable that reflects the importance given to the maintaining or increasing market share is not statistically significant, in line with [15]. However, similarly to environmental product innovations, giving importance to the increasing market demand for green products has also a strong positive effect on environmental process innovation. Most probably, product eco-innovators are able to develop process eco-innovations.

\section{CASE STUDIES}

\section{A. Ecoinnovation development in Poland}

Poland, since its accession to the EU in 2004, enabled to utilize EU funds, reduce the backlogs in transportation infrastructure and environmental protection and at the same time build a strong economy [22]. The state of the natural environment has significantly improved, while the resources productivity and energy intensity unfortunately have increased. During the last 20 years, energy consumption remained stable in spite of significant Gross Domestic Product (GDP) growth, due to energy efficiency improvement and changing the structure of economy. Nevertheless, the energy 
intensity index is still 2-3 times lower than the EU-27 average. In Poland, almost half (47\%) of the companies surveyed by Eurobarometer stated that material costs was half or more of their total production value [3]. Companies in Poland were the most likely to have introduced a new or significantly improved eco-innovative product or service, production process or organizational method in the past two years $(63 \%)$; companies in Hungary were the least likely to have done so $(27 \%)$. Regardless of the fact that the country policy in the area of eco-innovation misses synergy, the eco-innovations have been addressed via national policy strategies on environmental protection, product policy, energy efficiency in buildings, etc. The interest of Small Medium Enterprises (SME) in ecoinnovation is slowly growing, especially in relation to cost reduction possibilities, due to notably reduction of energy consumption and decreasing expenditures related to pollutant emissions [22].

The country also has many positive examples of ecoinnovations in energy and water management, hazardous waste treatment, solar energy, green banking and coke industry and a number of eco-innovation related programs and initiatives within clusters. On the other hand, development of eco-innovations in Poland is significantly hindered by numerous barriers. Eco-innovations in particular, remain outside the interest of decision makers policies which determine Poland's expectations towards the EU and future Structural Fund allocations for development objectives.

Lack of well-qualified and skillful specialist constitutes another large obstacle to development of eco-innovations in Poland. This is result of poor and ineffective system of education. Graduates of technological studies are in minority and staff available to work on eco-innovations is limited. There is a large difference between the business sphere, which is very innovative but still on a basic, everyday level, and administration and science. Due to insufficient information, access to eco-innovative solutions developed by the academic and science sector is limited.

Positive, albeit slow, changes are perceived in Poland in the area of eco-innovations. They do not immediately lead to a significant increase in the value of the eco-innovativeness EU Member States scoreboard index. The scoreboard applied 16 indicators grouped into thematic areas: eco-innovation inputs, eco-innovation activities, eco-innovation outputs, environmental outcomes and socio-economic outcomes. It shows how countries perform in different magnitudes of ecoinnovation compared to the European Union average and describes strengths and weaknesses. The Eco-IS complements other measurement approaches of innovativeness of EU countries and aims to promote a complex view on economic, environmental and social performance. Compared with 2011 Poland rank moved from the last place to the $25^{\text {th }}$ position. The increase occurred in the area of eco-innovation output. [23]
Eco-innovations still are giving the impression as "end of pipe, environmental protection technologies" rather than a cross- cutting innovations [4]. Transition to a low-carbon economy is perceived as a threat in companies and SMEs. Implementation of stringent environmental regulations is seen solely as a cost and not as an opportunity for building an innovative and competitive economy. Awareness on the benefits resulting from implementation of eco-innovative technologies among entrepreneurs and consumers in general is relatively low. Entrepreneurs tend to invest in cheapest technologies allowing them to achieve the commercial goal or meet the minimum legislative requirement. Many entrepreneurs and research organization fail to see benefits from cooperation.

The main barrier for Polish companies is lack of sufficient capital to invent and implement eco-innovation. Additionally, financial institutions face a significant risk connected with involvement in eco-innovative projects. This risk is related more to technological issues, i.e. the possibility to achieve expected parameters, than to financial ones. There are no sufficient funds to verify anticipated solutions, be it in a semitechnical form or as a pilot solution. This relates especially to a project finance situation, where a company is established only to implement a particular investment. If a project has undergone preliminary verification, banks or other financial institutions are more likely to provide a loan, as such verification reduces their risk. Venture capital funds are also lacking. Establishment of the National Centre for Research and Development and development of clusters should improve that situation.

There exist several eco-innovation good examples in Poland:

- Successful continuation of the program GreenEvo (Green Technologies Accelerator). This initiative of the Ministry of Environment supports Polish ecoinnovators, mostly SMEs transferring technologies all around the world. In 2011 alone, GreenEvo participants revenues increased by $31 \%$ on average, and their export revenues soared by $58 \%$. What is more $86 \%$ of companies made a trade offer to foreign customers, and $50 \%$ of them have signed distribution agreements with foreign partners [22]

- Establishing a number of eco-innovation oriented clusters e.g. Silesian Cluster of Environmental Technologies, Baltic Eco-energy cluster and Clean Energy Cluster of Malopolska and Podkarpackie (Eco-inovation in Poland: 2012 update).

- Participation of Poland in the Environmental Technologies Verification (ETV) Pilot Program of the European Union - a scheme supporting market uptake of eco-innovative technologies [22]. 


\section{B. Ecoinnovation development Denmark}

Denmark started its green economy transformation 40 years ago and has built up an environmental policy which dates back to its Environmental Protection Act in 1974 [24]. The leading position is mainly linked to Danish exports of renewable energy technologies, wind turbines, greater range of green technology. Denmark's competitiveness over the same period has deteriorated significantly due to high wage growth and poor progress on productivity (Ministry of Business and Growth Furthermore, the high taxes makes it difficult to attract highly qualified people for research and innovation. As a small country Denmark also has to rely more on exporting its technology and services in competition with other countries with similar ambitions. This is challenge compared with countries with larger internal markets. Eight growth teams have been established in areas where Danish companies have particular strengths and potentials. The growth teams are a hybrid type of public-private partnership with businesses, researchers, public sector officials and other stakeholders working together to improve the conditions for growth. Two growth teams are focusing on the green sector; one in the energy and climate and the other on water, bio and environmental solutions. In addition, other growth teams have focused on greening the sectors, for instance the maritime sector, agriculture and the design sector. The recommendations are now being put into action by the Government

In 2012 a new Energy Agreement - "Our Future Energy" was reached in Denmark. It contains a wide range of ambitious initiatives to bring Denmark closer to the target of $100 \%$ renewable energy in the energy and transport sectors by 2050 and a near-term objective of reducing greenhouse gas emissions in 2020 by $40 \%$ compared to 1990-level. The Agreement focuses especially on energy efficiency in households and industries as well as a comprehensive conversion of the energy sector through increased use of renewable energy, strong interconnectivity to neighbouring countries and new smart grid solutions. The Agreement includes that approximately $50 \%$ of electricity consumption should be supplied by wind power, more than $35 \%$ of final energy consumption supplied from renewable energy sources, and a continued bio-gas expansion. The Agreement provides provision for investments in the implementation of energy efficiency measures and renewable energy of DKK 90-150 billion towards 2020. This will stimulate innovation, for which there will be an increasing demand as the energy systems both in Denmark, in the EU and globally. The Agreement provides a stable framework for the Danish business community for years ahead. To strengthen competitiveness of Danish companies' emphasis has been placed on targeted energy efficiency measures and tax exemptions to industries inherently vulnerable to international competition with high energy intensiveness.
One of the Danish ecoinnovation examples is focusing on getting more out of less in terms of energy from wastewater and biomass. The plant consists of two treatment lines complementing each other: A wastewater treatment line and a biomass treatment line. These two treatment lines works in synergy: The wastewater treatment line is producing biomass as a result of the treatment process which is delivered as a cosubstrate to the biomass treatment that is producing biogas for energy production in form of electricity and a local resource circle and the plant is furthermore receiving organic household waste from the local municipality and organic by-products from the local industry. The biogas production is a way of reusing the energy resource from the biomass. The end product from the plant is a completely sanitized organic fertilizer containing the nutrients from the bio waste and wastewater ready to be used for new production in the agriculture.

Far offshore, wind conditions for wind turbines are excellent, but the sea is too deep for conventional seabed mounted towers to be economical. The possible solution are floating platforms which represent a much lower cost than conventional foundations, besides this the platforms also offers flexibility and can be assembled on shore or in shallow water and towed it out to sea. Floating Power Plant's floating offshore platform, the "Poseidon", combines the generation of Wind and Wave energy. WAVE: The Poseidon is based on a hydraulic power take-off system and is designed for location offshore in areas with considerable flux. WIND: The three wind turbines mounted on the platform can be standard offshore wind turbines.

\section{Econometric Study}

In order to identify the factors influencing on whether or not enterprises implemented eco-innovations, a multiple regression model was used, and $27 \mathrm{EU}$ enterprises were analysed. In particular variants of the model, the inclination for ecoinnovations measured as a proportion of enterprises which implemented particular kinds of environmentallyfriendly innovations in 2009-2010 was chosen as a dependent variable. Independent variables used in models were factors influencing the decisions by companies as to whether they should implement eco-innovations. For the given objects of our analysis, i.e. the 27 groups of enterprises from EU countries, the values of independent variables were calculated as weighted means, where the weights were fractions of inquired respondents assessing given factors as very important and somewhat important. 
TABLE II

RESULTS OF ECONOMETRIC ANALYSIS

\begin{tabular}{|c|c|c|c|c|c|c|}
\hline \multirow[b]{2}{*}{$\begin{array}{l}\text { Independent } \\
\text { variables }\end{array}$} & \multicolumn{6}{|c|}{ Dependent variables } \\
\hline & 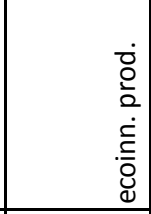 & 岕 & 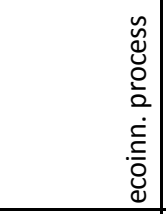 & 岕 & 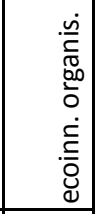 & 岕 \\
\hline Constant & $-0,63$ & 7,88 & 13,7 & 9,71 & $-1,32$ & 11,37 \\
\hline $\begin{array}{l}\text { High material } \\
\text { prices }\end{array}$ & $0,34^{*}$ & 0,1 & 0,42 & 0,22 & $0,31 *$ & 0,15 \\
\hline $\begin{array}{l}\text { High energy } \\
\text { prices }\end{array}$ & & & $-0,71^{*}$ & 0,29 & & \\
\hline $\begin{array}{l}\text { Expected } \\
\text { high energy } \\
\text { prices. }\end{array}$ & & & $0,48^{*}$ & 0,22 & & \\
\hline R2 & 0,42 & & 0,32 & & 0,15 & \\
\hline$F$ ( $p$ value) & \begin{tabular}{|l|}
$9,86(<0,00$ \\
$1)$
\end{tabular} & & $3,61(<0.02)$ & & $6,36 \mid<0$ & $0,04)$ \\
\hline
\end{tabular}

$\star \mathrm{p}<0.05$

According to the results of the calculations, the only factor which positively influenced product eco-innovation implementation appeared to be an increase in high material prices. With respect to process eco-innovations it may be concluded that the current high prices of energy used in production processes and expected high energy price were only significant variables, and higher energy prices acted contrary to our theory-based expectations as a sedative to the implementation of new or significantly improved ecoinnovative production processes or new methods. Considering organizational ecoinnovation, the only significant variable was high material prices. Other variables were removed from the model. Those results should be illustrative.

\section{CONCLUSION}

One solution on the way to green economy are ecoinnovations. Positive examples can be observed in European countries and illustrations were presented from two countries: Poland and Denmark. Nevertheless, considerable concerns related to the development of eco-innovativeness are observed in some European countries, particularly new member countries, including Poland. First, politicians do not fully recognize the significance of eco-innovations, or generally- innovations. Strong lobby supports obsolete industries and it is not interested in development of ecoinnovations. On the one hand, there is no pressure on research in new eco-innovative solutions. On the other, academic and
$R \& D$ centers are unable to satisfy the demands of the industry. It is of key importance that eco-innovations are perceived as the driving factor of the third transformation in Poland and other EU new members (following system transformation and the EU accession). The state should play the key role in this process - on the one hand it should inspire the demand for eco-innovations and on the other it should assure conditions for increasing interest in such solutions. Despite significant progress, the new member countries economy has low productivity and high GHG emission intensity. Countries still have a lot to do to become an economy of high material and energy efficiency. This includes development of a necessary legal and institutional background. Such a transformation also requires fundamental changes in education and the behavioral patterns of citizens and companies so that we become a society of sustainable material consumption and move toward a green economy, where development is decoupled from material and energy use.

Main factor influencing product ecoinnovation seem to be high price of material.

\section{ACKNOWLEDGEMENT}

The project was financed with The National Center for Science in Poland awarded based on the decision number DEC-2013/11 / B / HS4 / 02122.

\section{REFERENCES}

[1] L. Woźniak, J. Strojny and E. Wojnicka, „Jak budować przewage konkurencyjną dzięki ekoinnowacyjności?, Polska Agencja Rozwoju Przedsiębiorczości,, Warszawa, 2010.

[2] C. Fussler and T. James, "Driving Eco-innovation: a breakhrough discipline for innovation and sustainability", London: Pitman publishing, 1997.

[3] Gallup, "Attitudes of European entrepreneurs towards eco-innovation". Analytical report, Flash Eurobarometer., p. 315, 2011.

[4] Eco-innovation observatory, "Closing The Eco-Innovation Gap An economic opportunity for business", European Union, 2011.

[5] L. Woźniak, J. Striojny and E. Wojnicka, „Ekoinnowacyjność dzis and jutro-wyzwania, bariery rozwoj oraz instrumenty wsparcia," PARP, 2010 .

[6] J. Horbach, "Determinants of environmental innovation - New evidence from German panel data sources", Research Policy, Elsevier, vol. 37(1), pp. 163-173, 2008

[7] K. Frondel, J. Horbach and K. Rennings, End-of-Pipe or Cleaner Production? An Empirical Comparison of Environmental Innovation Decisions Across OECD Countries," Business Strategy and the Environment, pp. 571-584, 2007.

[8] D. Kammerer, "The effects of customer benefit and regulation on environmental product innovation. Empirical evidence from appliance manufacturers in Germany", Ecological Economics, Vol. 68, p. 22852295, pp. 2285-2295, 2009.

[9] D. Popp, "International Innovation and Diffusion of Air Pollution Control Technologies: The Effects of NOx and SO2 Regulation in the US, Japan, and Germany" 1, p 6-71.," Journal of Environmental Economics and Management, tom 51, nr 1, pp. 6-71, 2006.

[10] P. Gonzales, "The empirical analysis of the determinants for environmental technological change: a research agenda", Ecological Economics, Volume: 68, , pp. 861-875, 2009.

[11] T. Arimura and i. A. J. N. Hibik, "An empirical analysis of environmental R\&D: what encourages facilities", in: Environmental 
Policy and Corporate Behaviour, Edward Elgar, 2007.

[12] K. Rennings, ,Redefining innovation - eco-innovation research and the contribution from ecological economics," Ecological Economics, 32, pp. 319-322, 2000.

[13] A. Kemp and Pearson, „Measuring eco-innovation, final report of MEI project for DG Research of the European Commission.," 2008.

[14] J. Horbach, C. Rammer and K. Rennings, „Determinants of Ecoinnovations by Type of Environmental Impact The Role of Regulatory Push/Pull, Technology Push and Market Pull Discussion Paper No. 11027,year," ZEW, 2009.

[15] T. Cleff and K. Rennings, (1999), "Determinants of environmental product and process innovation.," Eur. Env., 9, pp. 191-201, 1999.

[16] K. Rehfeld, K. Rennings and A. Ziegle, ”Determinants of Environmental Product Innovations and the Role of Integrated Product Policy - An Empirical Analysis," Ecological Economics , Vol. 61, pp. 91-100, 2007.

[17] K. Green, A. McMeekin and A. Irwin, "Technological trajectories and R \& D for environmental innovation in UK firms. pp. 1047-1059.," Futures 26, pp. 1047-1059, 1994.

[18] J. Horbach, K. Rennings and C. Rammer, "Determinants of eco- innovations by type of environmental impact - The role of regulatory push/pull, technology push and market pull, (2012), p. 112-122," Ecological Economics, pp. 112-122, 2012.

[19] K. Rennings and C. Rammer, „The Impact of Regulation-Driven Environmental Innovation on Innovation Success and Firm Performance.," Industry and Innovation, 18, pp. 255-283, 2011.

[20] Eurostat, „Community Innovation Survey/CIS/ Eurostat, (2010). http://epp.eurostat.ec.europa.eu/portal/page/portal/microdata/cis," 2010.

[21] Ecoinnovation observatory, 2012.

[22] A. Kassenberg and P. Kassenberg, "Ecoinnovation in Poland, Country Profile: Poland," Ecoinnovation Observatory, 2011.

[23] Eco-innovation observatory, „Eco-innovation in Poland: 2012 update,” 2012.

[24] A. Varga, "Country Profile 2013: Denmark," Ecoinnovation Observatory, European Commission, 2013 